\title{
CRITICAL SUCCESS FACTOR FOR IMPLEMENTING KM IN GOVERNMENT HUMAN CAPITAL MANAGEMENT: CASE STUDY BADAN KEPEGAWAIAN NEGARA
}

\author{
Elin Cahyaningsih and Dana Indra Sensuse \\ Faculty of Computer Science, Universitas Indonesia, \\ Kampus Baru UI Depok, Jawa Barat, 16424, Indonesia \\ Email: elin.cahyaningsih@ui.ac.id
}

\begin{abstract}
Nowadays, knowledge management in organization became a trend strategy in order to improve organization performance. But unfortunately, it's a big challenge to implementing knowledge management in organization, because it's relatively new and not many people knew about this. This research is done in order to realize bureaucratic reform in government service improvement according to PERMENPAN No. 14 Tahun 2011 is about knowledge management (KM) implementation in government. Knowledge management cannot be separated from human capital as an intangible asset in organization which has an important role to the success of organization goals. This conducted research aims to identify critical success factor of KM implementation in Indonesian government human capital management case study: Badan Kepegawaian Negara. Stages of this research are literature study, data collection using interviews, observation, and group discussion organization to explore and discovering critical success factor for KM implementation. Data analysis using descriptive statistic, delphi method and expert judgment in order to define critical success factor of implementing KM in government human capital management: case study in Badan Kepegawaian Negara. The result shows that several critical success factors for KM implementation in the government human capital management are organization culture, leadership, organization structure, HR/HC (knowledge, skill, attitude), HR/HC process (acquisition, development, engagement, retention) and policy.
\end{abstract}

Keywords: Knowledge Management, Human Capital, Critical Success Factor, Delphi Method

\begin{abstract}
Abstrak
Saat ini, manajemen pengetahuan (knowledge management) dalam organisasi menjadi sebuah trend strategi dalam rangka untuk meningkatkan performa organisasi. Tetapi sangat disayangkan bahwa hal ini menjadi sebuah tantangan yang besar untuk menerapkan manajemen pengetahuan, karena ilmu ini relative baru dan tidak banyak orang mengetahuinya. Penelitian ini dilakukan dalam rangka untuk mewujudkan reformasi birokrasi dalam peningkatan pelayanan pemerintah berdasarkan PERMENPAN No. 14 Tahun 2011 tentang penerapan manajemen pengetahuan (knowledge management) di pemerintahan. Manajemen pengetahuan tidak bisa dipisahkan dari human capital sebagai aset yang tidak berwujud (intangible asset) dalam organisasi yang memiliki peran penting dalam mewujudkan tujuan organisasi. Penelitian ini dilakukan untuk mengidentifikasi critical success factor (CSF) penerapan manajemen pengetahuan dalam pengelolaan human capital di pemerintahan Indonesia dengan studi kasus Badan Kepegawaian Negara. Tahapan penelitian ini meliputi studi literature, pengeumpulan data dengan wawancara, observasi dan diskusi kelompok untuk menyelidiki dan menemukan critical success factor penerapan manajemen pengetahuan (KM). Analisis data menggunakan statistik deskriptif, delphi method dan expert judgement dalam rangka untuk menentukan critical success factor penerapan manajemen pengetahuan (KM) dalam pengelolaan human capital di pemerintahan: studi kasus di Badan Kepegawaian Negara. Hasil dari penelitian ini menenjukan bahwa beberapa critical success factors penerapan manajemen pengetahuan (KM) dalam pengelolaan human capital di pemerintahan adalah budaya organisasi, kepemimpinan, struktur organisasi, sumber daya manusia (pengetahuan, ketrampilan, sikap), SDM proses (acquisition, development, engagement, retention) dan kebijakan.
\end{abstract}

Kata kunci: Knowledge Management, Human Capital, Critical Success Factor, Delphi Method 



\section{Introduction}

Ministry as mandated by Undang-undang Dasar 1945 is responsible to assist president perform the government. Knowledge management is a hot issue in the development of organizational management, accordance with the regulation of MENPAN \& RB No. 14 Tahun 2011 about implementtation of knowledge management. The ministry is expected to implement $\mathrm{KM}$ in order to improve the effectiveness and efficiency of organizational activity due the bureaucratic reform goal. Ministry duties and management functions cannot be separated with human capital role. Human capital as intellectual capital is intangible organization asset that play a role in creating KM. Organizational human capital, support organizational business process therefore human capital should be managed and employed efficiently [1]. Whereas the assessment of KM success in human capital can be seen from learning process, adaptability and employee job satisfaction [2].

The good human capital management will increase organization competitive advantage, therefore knowledge management challenges are to find the critical success factors for implementing KM in human capital management. This conducted research aims to identify critical success factor of KM implementation in Indonesian government human capital management case study: Badan Kepegawaian Negara. This research scope is case study in Biro Kepegawaian Badan Kepegawaian Negara as human capital manager, which respondents are the knowledge workers in each division.

\section{Knowledge Management}

Knowledge management are activities for discovering, capturing, sharing and applying knowledge in order to increase knowledge with cost effecttive to achieve organizational goals [2]. Turban et all in their research told that $\mathrm{KM}$ is a process to identify, select, manage, transmit and disseminate information for problem solving, strategic planning and decision making, $\mathrm{KM}$ also can increase the value of organization intellectual capital [3]. Based on some opinion above, KM can be defined as an exploration process through generate, capture, codify and transfer knowledge from organizational knowledge resource to achieve organizational goals.

\section{Critical Success Factor}

Andrew et al explain that critical success factor are few thing that must done for a manager and organization in order to ensure success and represent the high performance of organization [4]. Key success factors are critical factor that support organizational performance, usually as internal factor which can be controlled by the organization $[5]$.

\section{Human Capital and Human Capital Manage- ment}

Intellectual capital consists of human capital and structure capital which are the most valuable resources in organization. Aldi Sent explain that human capital as an aggregate of knowledge, skill, working experiences and employees motivation. While Kaplan et al state that human capital is an intellectual capital which is reflect minds, knowledge, creativity and decision making by an individual in the organization [6]. It can be concluded that human capital is intangible asset that owned by organization, consist of knowledge, competency, experience and individual skill.

Human capital management is method that manage employee as intangible asset of the organization to reach organization competitive advantages [7]. Human capital management is managing organizational competencies and individual competencies with human capital management process.

\section{KM Implementation in Government Human Capital Management}

KM implementation in human capital began to be developed through Human Capital Management Program in organization. Effective KM implementtation in human capital is the human capital strategy that consists of competency management, performance management, change management and knowledge management [8]. Tang et all propose that effective KM need policy, concept and HR development plan based KM [9]. Learning the $\mathrm{KM}$ application is to improve human capital in order to establish social and organizational relationships. It's needed for simplify the management and efficiency of HR in order to achieve organizational success [1]. Application of KM in government, especially in human capital management is still limited in line with bureaucracy reform program.

\section{Delphi Method and Expert Judgment}

Delphi method is used for discuss and communicate complex problem in group of expert in terms to find the best solution for the problem [10]. Hsu et al explain that Delphi technique is used for evaluation, fact-finding, explore an issue or discovering the information of specific topic [11]. Some application for delphi method are used for forecasting, prioritization, and framework. The Delphi analysis method according to Okoli et al divided into three general steps: brainstorming for important factor, narrowing down the original list to the 
most important ones and ranking the list of important factors [10].

Expert judgment is a method that required for decision models when there is a controversy among the expert to conclusive and interpreted the problem solution [12].

\section{Previous Study}

The following outlined previous research related key success factor for implementing KM in Government Human Capital Management, to provide an overview of the research that has been carried. It is shown in table 1 .

According to previous study in public sector, there still an opportunity for research because the challenges for hierarchical and bureaucratic organizational in Indonesian government. Although some government in other country have started to implementing KM, especially in human capital area for supporting competitive advantage and organization goal to achieve a good government.

\section{Methodology}

The stage of research involves five steps: introduction of research background, purpose, also scope of the study, explain theoretical and previous study from other researcher related to the topic to find the key success factor, data collection methods with observation, interviews and group discussion as an information expert in Biro Kepegawaian $\mathrm{BKN}$, data processing using statistics descriptive and analysis methods using delphi methods and expert judgment from the human capital managers in Biro Kepegawaian.

Dephi Methods have a three steps there are:

a. Brainstorming for the important factor that found from literature review. The researcher explain about these finding factors of implementing $\mathrm{KM}$ in government human capital management to the knowledge worker in each division for further discussion in group.

b. Narrowing down the original list to the most important ones by discussed it in a group to get a feed back and suggestions about those factors.

c. Ranking the list of important factors as the most important factor for their organization. Each respondent write the list of factor by rank from the most important factor into the unimportant factor

The finding factors result from the delphi methods were judgment by an expert in Biro Kepegawaian $\mathrm{BKN}$ as a human capital managers to find the priority factor implementing $\mathrm{KM}$ in government human capital management. Expert judgment was conducted with group discussion among the experts.

Sample of critical success factor that used in this research were from 15 (fifteen) respondent of human resource workers and supervisor in Badan Kepegawaian Negara. All data sample were analysis and treated to find the percentage of importance and rank. The next step were using data sample from 5 (five) human resource managers in middle level in Badan Kepegawaian Negara as an expert respondent to define priority of the CSF factors.

TABLE 1

\begin{tabular}{|c|c|c|c|}
\hline \multicolumn{4}{|c|}{ PREVIOUS STUdy OUTLINE } \\
\hline No & Researcher & Object & $\begin{array}{l}\text { Finding } \\
\text { (critical success factor) }\end{array}$ \\
\hline 1. & $\begin{array}{l}\text { (Asoh et al, } \\
2002)\end{array}$ & $\begin{array}{l}\text { US } \\
\text { Government }\end{array}$ & $\begin{array}{l}\text { trust, org. culture, mo- } \\
\text { tivation, community of } \\
\text { practice, IT, infrastruc- } \\
\text { ture, leadership, best } \\
\text { practice, service }\end{array}$ \\
\hline 2. & $\begin{array}{l}\text { (Cong and } \\
\text { Pandya 2003) }\end{array}$ & $\begin{array}{l}\text { US } \\
\text { Government }\end{array}$ & $\begin{array}{l}\text { HR/HC (knowledge, } \\
\text { skill attitude), process } \\
\text { HR/HC, IT, org. cul- } \\
\text { ture, org. structure, } \\
\text { trust }\end{array}$ \\
\hline 3. & $\begin{array}{l}\text { (Winkelen } \\
\text { and } \\
\text { McKenzie } \\
\text { 2007) }\end{array}$ & $\begin{array}{l}\text { Multi- } \\
\text { national } \\
\text { private and } \\
\text { public } \\
\text { sector in } \\
\text { UK }\end{array}$ & $\begin{array}{l}\text { KM process (capture/ } \\
\text { transfer, sharing), co- } \\
\text { mmunity of practice, } \\
\text { individual and organi- } \\
\text { zation initiative, HR/ } \\
\text { HC Process, policy, le- } \\
\text { adership, } \\
\text { infrastructure, }\end{array}$ \\
\hline
\end{tabular}

4. (Shirazi et al Mashhad $\quad \mathrm{HR} / \mathrm{HC}$ (knowledge, $\begin{array}{lll}\text { 2010) } & \begin{array}{l}\text { Mashhad } \\ \text { provincial }\end{array} \text { skill attitude), org. cul- }\end{array}$ municipality ture, org. structure, leadership, community of practice, commitment, IT and infrastructure, policy

5. (Noor and Electronic HR/HC (knowledge, Salim 2011) Government skill attitude), IT, org. agencies in culture, experience, Malaysia position

6. (Biygauntane UAE's IT, leadership, KM and Al-Yahya Dubai process, HR/HC (kno2011) Sector wledge, skill attitude), Public Org. Culture

\section{Result and Analysis}

This research object and respondent for delphi technique are 15 knowledge workers in 5 division of Human Resource Manager in Badan Kepegawaian Negara (Human Resource Development, Human Resource Recruitment, Retirement and Mutation, Human Resource Administration and Law, Human Resource Organization and Management, Human Resource Welfare). The result is shown in Table 2. 
First step of Delphi method is brainstorming for the important factor that found from literature review. In this step all respondents were interviewed about key finding of each previous work and eliminate the same factor into final consolidated lists that shown in Table 3.

TABLE 2

LIST OF DELPHI TECHNIQUE RESPONDENT

\begin{tabular}{|c|c|c|c|c|}
\hline No & Name & Position & Division & \\
\hline 1. & $\begin{array}{l}\text { Mrs. } \\
\text { S }\end{array}$ & $\begin{array}{l}\text { Employee career } \\
\text { counselor }\end{array}$ & $\begin{array}{l}\text { Human } \\
\text { Development }\end{array}$ & Resource \\
\hline 2. & Mr. A & $\begin{array}{l}\text { Head Subdivision } \\
\text { of employee } \\
\text { welfare }\end{array}$ & $\begin{array}{l}\text { Human } \\
\text { Welfare }\end{array}$ & Resource \\
\hline 3. & $\begin{array}{l}\text { Miss. } \\
\text { D }\end{array}$ & $\begin{array}{l}\text { Employee career } \\
\text { counselor }\end{array}$ & $\begin{array}{l}\text { Human } \\
\text { Development }\end{array}$ & Resource \\
\hline 4. & $\begin{array}{l}\text { Miss. } \\
\mathrm{K}\end{array}$ & $\begin{array}{l}\text { Employee } \\
\text { performance } \\
\text { analyzer }\end{array}$ & $\begin{array}{l}\text { Human } \\
\text { Development }\end{array}$ & Resource \\
\hline 5. & Mr. J & $\begin{array}{l}\text { Employee career } \\
\text { development } \\
\text { analyzer }\end{array}$ & $\begin{array}{l}\text { Human } \\
\text { Development }\end{array}$ & Resource \\
\hline 6. & Mr. N & $\begin{array}{l}\text { Employee legal } \\
\text { issues reviewers }\end{array}$ & $\begin{array}{l}\text { Human } \\
\text { Administration } \\
\text { Law }\end{array}$ & $\begin{array}{r}\text { Resource } \\
\text { and }\end{array}$ \\
\hline 7. & $\begin{array}{l}\text { Mrs. } \\
\text { W }\end{array}$ & $\begin{array}{l}\text { Head Subdivision } \\
\text { of Human } \\
\text { Resource } \\
\text { Recruitment }\end{array}$ & $\begin{array}{l}\text { Human } \\
\text { Recruitment, } \\
\text { Retirement } \\
\text { Mutation }\end{array}$ & Resource \\
\hline 8. & $\begin{array}{l}\text { Mrs. } \\
\text { Y }\end{array}$ & $\begin{array}{l}\text { Head Subdivision } \\
\text { of Human } \\
\text { Resource } \\
\text { Administration }\end{array}$ & $\begin{array}{l}\text { Human } \\
\text { Administration } \\
\text { Law }\end{array}$ & $\begin{array}{r}\text { Resource } \\
\text { and }\end{array}$ \\
\hline 9. & Mr. S & $\begin{array}{l}\text { Head Subdivision } \\
\text { of Human } \\
\text { Resource } \\
\text { Organization }\end{array}$ & $\begin{array}{l}\text { Human } \\
\text { Organization } \\
\text { Management }\end{array}$ & $\begin{array}{r}\text { Resource } \\
\text { and }\end{array}$ \\
\hline 10. & Mr. D & $\begin{array}{l}\text { Employee } \\
\text { procurement } \\
\text { analyzer }\end{array}$ & $\begin{array}{l}\text { Human } \\
\text { Recruitment, } \\
\text { Retirement } \\
\text { Mutation }\end{array}$ & $\begin{array}{r}\text { Resource } \\
\text { and }\end{array}$ \\
\hline 11. & $\begin{array}{l}\text { Miss. } \\
\mathrm{K}\end{array}$ & $\begin{array}{l}\text { Employee } \\
\text { procurement } \\
\text { analyzer }\end{array}$ & $\begin{array}{l}\text { Human } \\
\text { Recruitment, } \\
\text { Retirement } \\
\text { Mutation }\end{array}$ & Resource \\
\hline 12. & $\begin{array}{l}\text { Mrs. } \\
\text { S }\end{array}$ & $\begin{array}{l}\text { Employee legal } \\
\text { issues reviewers }\end{array}$ & $\begin{array}{l}\text { Human } \\
\text { Administration } \\
\text { Law }\end{array}$ & $\begin{array}{r}\text { Resource } \\
\text { and }\end{array}$ \\
\hline 13. & Mr. G & $\begin{array}{l}\text { Employee data } \\
\text { processing staff }\end{array}$ & $\begin{array}{l}\text { Human } \\
\text { Recruitment, } \\
\text { Retirement } \\
\text { Mutation }\end{array}$ & Resource \\
\hline 14. & $\begin{array}{l}\text { Mrs. } \\
\text { A }\end{array}$ & Financial staff & $\begin{array}{l}\text { Human } \quad F \\
\text { Development }\end{array}$ & Resource \\
\hline 15. & $\begin{array}{l}\text { Mrs. } \\
\text { AI }\end{array}$ & $\begin{array}{l}\text { Public } \\
\text { staff }\end{array}$ & $\begin{array}{l}\text { Human } \\
\text { Administration } \\
\text { Law }\end{array}$ & $\begin{array}{r}\text { Resource } \\
\text { and }\end{array}$ \\
\hline
\end{tabular}

Second step is narrowing down the original list to the most important ones by discussed it in a group to get a feed back and suggestions about those factor. Respondents do the group discussion to find critical success factor from the list. It is shown in Table 4.

In this second step of Delphi method shows percentage of each factor from discussion session. The result of this step is reducing the unimportant factor which is has percentage under $50 \%$ of respondents.

This step also discovering two new factors there are integrity and adversity quotient, but those factor are rejected because not eligible from respondents opinion.

TABLE 3

LIST OF THE CRITICAL SUCCESS FACTOR FROM PREVIOUS WORK

\begin{tabular}{cll}
\hline No. & \multicolumn{1}{c}{ Critical Success Factor } & \multicolumn{1}{c}{ Previous Work } \\
\hline 1 & Trust & {$[13],[14]$} \\
2. & Motivation & {$[13]$} \\
3. & Community of practice & {$[13],[15],[16]$} \\
4. & Infrastructure & {$[13],[15],[16]$} \\
5. & Leadership & {$[13],[15],[16],[17]$} \\
6. & Best practice & {$[13]$} \\
7. & Service & {$[13]$} \\
8. & HR/HC (knowledge, skill, & {$[14],[16],[17]$,} \\
& attitude) & {$[18]$} \\
9. & Organizational culture & {$[13],[14],[16]$,} \\
10. & Organization structure & {$[17],[18]$} \\
11. & Organization and individual & {$[14],[16]$} \\
12. & Politiative & {$[15]$} \\
13. & Experince & {$[15],[16]$} \\
14. & HR/HC process & {$[18]$} \\
15. & Position & {$[14],[15]$} \\
16. & IT & {$[18]$} \\
17. & KM process & {$[13],[14],[16]$,} \\
18. & Commitment & {$[17],[18]$} \\
& & {$[15],[17]$}
\end{tabular}

TABLE 4

THE CRITICAL SUCCESS FACTORS PERCENTAGE FROM GROUP DISCUSSION SESSION

\begin{tabular}{|c|c|c|c|}
\hline \multicolumn{4}{|c|}{ DISCUSSION SESSION } \\
\hline \multirow[b]{2}{*}{ CSF } & \multicolumn{2}{|c|}{ \% Respondent } & \multirow{2}{*}{$\begin{array}{l}\text { Result } \\
(>50 \%)\end{array}$} \\
\hline & Important & $\begin{array}{c}\text { Not } \\
\text { Important }\end{array}$ & \\
\hline Motivation & $7 \%$ & $93 \%$ & Rejected \\
\hline $\begin{array}{l}\text { Community } \\
\text { practice }\end{array}$ & $60 \%$ & $40 \%$ & Accepted \\
\hline Infrastructure & $53 \%$ & $47 \%$ & Accepted \\
\hline Leadership & $93 \%$ & $7 \%$ & Accepted \\
\hline Best practice & $20 \%$ & $80 \%$ & Rejected \\
\hline Service & $33 \%$ & $67 \%$ & Rejected \\
\hline $\begin{array}{l}\text { HR/HC (knowledge, } \\
\text { skill, attitude) }\end{array}$ & $87 \%$ & $13 \%$ & Accepted \\
\hline $\begin{array}{l}\text { Organizational } \\
\text { culture }\end{array}$ & $73 \%$ & $27 \%$ & Accepted \\
\hline $\begin{array}{l}\text { Organization } \\
\text { structure }\end{array}$ & $60 \%$ & $40 \%$ & Accepted \\
\hline $\begin{array}{l}\text { Organization and } \\
\text { individual initiative }\end{array}$ & $27 \%$ & $73 \%$ & Rejected \\
\hline Policy & $60 \%$ & $40 \%$ & Accepted \\
\hline Experience & $20 \%$ & $80 \%$ & Rejected \\
\hline $\begin{array}{l}\text { HR/HC process } \\
\text { (acquisition, } \\
\text { development, } \\
\text { engagement, } \\
\text { retention) }\end{array}$ & $67 \%$ & $33 \%$ & Accepted \\
\hline Position & $13 \%$ & $87 \%$ & Rejected \\
\hline IT & $60 \%$ & $40 \%$ & Accepted \\
\hline KM process & $60 \%$ & $40 \%$ & Accepted \\
\hline Commitment & $20 \%$ & $80 \%$ & Rejected \\
\hline Integrity $*$ & $13 \%$ & $87 \%$ & Rejected \\
\hline Adversity quotient $*$ & $13 \%$ & $87 \%$ & Rejected \\
\hline
\end{tabular}


There are ten factor which is accept from this step, there are community of practice, leadership, HR/HC (knowledge, skill and attitude), organizational culture, organization structure, policy, HR/HC process (acquisition, development, engagement, retention), IT, KM process, infrastructure.

TABLE 5

THE CRITICAL SUCCESS FACTORS RANK

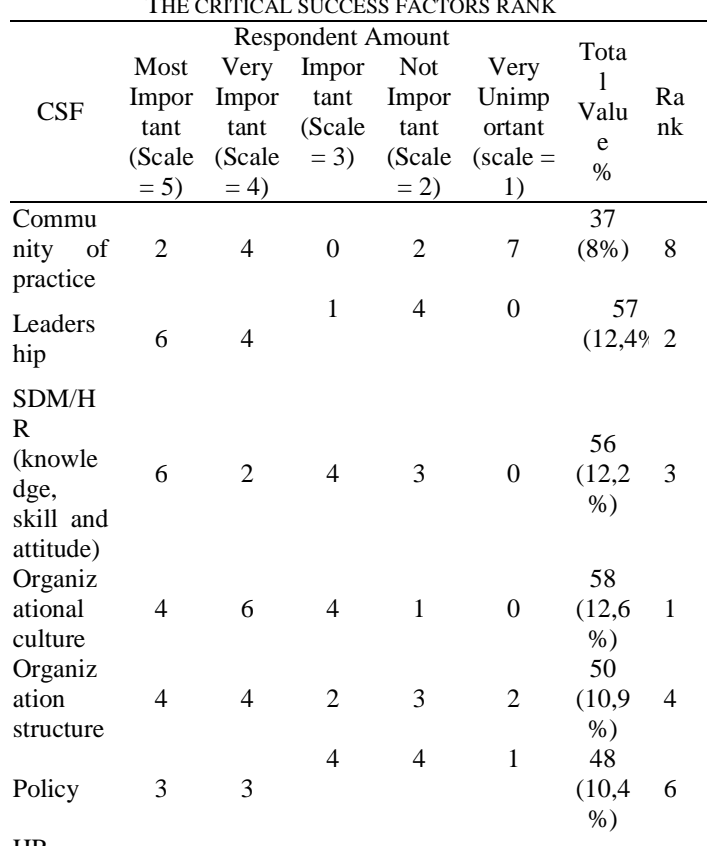

HR

process

(acquisit

ion,

develop

$\begin{array}{llllllll}\text { ment, } & 3 & 1 & 3 & 5 & 3 & (10,7 & 5\end{array}$

engagem

ent,

retention

)

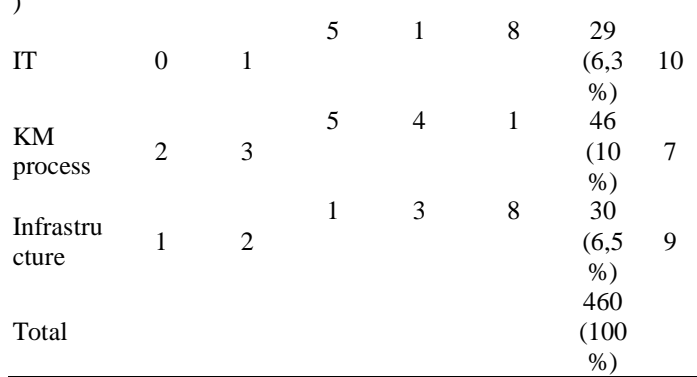

The last step is ranking the list of important factors as the most important factor for their organization. Each respondent write the list of factor by rank from the most important factor into the unimportant factor. The critical success factors rank from this technique are shown in table V.
TABLE 6

LIST OF EXPERT IN EXPERT JUDGMENT SESSION

\begin{tabular}{|c|c|c|c|c|c|}
\hline No & Name & \multicolumn{4}{|l|}{ Position } \\
\hline 1. & Mrs. A & \multicolumn{4}{|c|}{ Head division of Human Resource Development } \\
\hline 2. & Mr. JH & \multicolumn{4}{|c|}{$\begin{array}{l}\text { Head division of Human Resource Recruitment, } \\
\text { Retirement and Mutation }\end{array}$} \\
\hline 3. & Mr.J & \multicolumn{4}{|c|}{$\begin{array}{l}\text { Head division Human Resource Administration } \\
\text { and Law }\end{array}$} \\
\hline 4. & Mrs. C & \multicolumn{4}{|c|}{$\begin{array}{l}\text { Head subdivision of Human Resource Counceling } \\
\text { and Performance }\end{array}$} \\
\hline 5. & Mrs. E & \multicolumn{4}{|c|}{$\begin{array}{l}\text { Head subdivision of Human Resource Career } \\
\text { Development }\end{array}$} \\
\hline \multirow{2}{*}{\multicolumn{6}{|c|}{$\begin{array}{c}\text { TABLE } 7 \\
\text { PERCENTAGE OF CSF FROM EXPERT JUDGMENT }\end{array}$}} \\
\hline & & & & & \\
\hline \multirow{2}{*}{\multicolumn{3}{|c|}{ CSF }} & \multicolumn{2}{|c|}{$\%$ Expert } & \multirow{2}{*}{$\begin{array}{l}\text { Result } \\
>50 \%\end{array}$} \\
\hline & & & Important & $\begin{array}{c}\text { Not } \\
\text { Important }\end{array}$ & \\
\hline \multicolumn{3}{|c|}{ Community of practice } & $40 \%$ & $60 \%$ & Rejected \\
\hline \multicolumn{3}{|c|}{ Leadership } & $100 \%$ & $0 \%$ & Accepted \\
\hline \multicolumn{3}{|c|}{$\begin{array}{l}\mathrm{HR} / \mathrm{HC} \text { (knowledge, skill } \\
\text { and attitude) }\end{array}$} & $80 \%$ & $20 \%$ & Accepted \\
\hline \multicolumn{3}{|c|}{ Organizational culture } & 10 & $0 \%$ & Accepted \\
\hline \multicolumn{3}{|c|}{ Organization structure } & $100 \%$ & $0 \%$ & Accepted \\
\hline \multicolumn{3}{|c|}{ Policy } & $60 \%$ & $40 \%$ & Accepted \\
\hline \multicolumn{3}{|c|}{$\mathrm{HR} / \mathrm{HC}$ process } & & $40 \%$ & \\
\hline \multicolumn{3}{|c|}{$\begin{array}{l}\text { (acquisition, development, } \\
\text { engagement, retention) }\end{array}$} & $60 \%$ & & Accepted \\
\hline \multicolumn{3}{|c|}{ IT } & $40 \%$ & $60 \%$ & Rejected \\
\hline \multicolumn{3}{|c|}{ KM process } & $40 \%$ & $60 \%$ & Rejected \\
\hline \multicolumn{3}{|c|}{ Infrastructure } & $40 \%$ & $60 \%$ & Rejected \\
\hline
\end{tabular}

TABLE 8

RANK OF CSF FROM EXPERT JUDGMENT

\begin{tabular}{|c|c|c|c|c|c|}
\hline \multicolumn{6}{|c|}{ Expert Amount } \\
\hline $\mathrm{CSF}$ & $\begin{array}{c}\text { Very } \\
\text { Important } \\
(\text { scale }= \\
5)\end{array}$ & $\begin{array}{c}\text { Important } \\
(\text { scale }= \\
3)\end{array}$ & $\begin{array}{c}\text { Not } \\
\text { Important } \\
(\text { Scale }= \\
1)\end{array}$ & $\begin{array}{c}\text { Total } \\
\text { Value } \\
\%\end{array}$ & Rank \\
\hline Leadership & 4 & 1 & 0 & $\begin{array}{c}23 \\
(21 \%)\end{array}$ & 2 \\
\hline $\begin{array}{l}\mathrm{HR} / \mathrm{HC} \\
\text { (knowledge, } \\
\text { skill and } \\
\text { attitude) }\end{array}$ & 1 & 3 & 1 & $\begin{array}{c}15 \\
(14 \%)\end{array}$ & 4 \\
\hline $\begin{array}{l}\text { Organizational } \\
\text { culture }\end{array}$ & 5 & 0 & 0 & $\begin{array}{c}25 \\
(23 \%)\end{array}$ & 1 \\
\hline $\begin{array}{l}\text { Organization } \\
\text { structure }\end{array}$ & 3 & 2 & 0 & $\begin{array}{c}21 \\
(19 \%)\end{array}$ & 3 \\
\hline Policy & 1 & 2 & 2 & $\begin{array}{c}13 \\
(12 \%)\end{array}$ & 5 \\
\hline $\begin{array}{l}\mathrm{HR} / \mathrm{HC} \\
\text { process }\end{array}$ & & & & $\begin{array}{c}13 \\
(12 \%)\end{array}$ & \\
\hline $\begin{array}{l}\text { (acquisition, } \\
\text { development, } \\
\text { engagement, } \\
\text { retention) }\end{array}$ & 2 & 1 & 2 & & 5 \\
\hline TOTAL & & & & $\begin{array}{c}110 \\
(100 \%)\end{array}$ & \\
\hline
\end{tabular}

Table $\mathrm{V}$ shows that CSF rank from the factor list are organizational culture, leadership, HR/HC (knowledge, skill, attitude), organization structure, HR/HC process (acquisition, development, engagement, retention), policy, KM process, community of practice, infrastructure and IT. 
These finding factors were judgment by 5 experts in Human Resource Manager in Badan Kepegawaian Negara by using expert judgment method to find the priority factor implementing $\mathrm{KM}$ in government human capital management. The results are shown in table VI-VII.

\section{Conclusion}

Key success factor implementing KM in Human Capital Management are used for design the KM environment in organization and for measurement the KM implementation through these factor. These six critical success factor from this research in BKN are organizational culture, leadership, organizational structure, HR/HC (knowledge, skill, attitude), HR/HC process (acquisition, development, engagement and retain) and the last is policy. The explanation of each factor will be elaborate in this chapter.

Organizational culture conducted as a role of procedure, program, policy, and attitude. Organizational culture also determines their goals and competitive advantages. According to Mozaffari, organizational culture is a multidimensional and multi level concept that can be define as an assumption, belief, perceptions, feeling, thought that share among organization member which is shown in organizational strategies as a procedure an action to achieve their goals [19].

The first factors is leadership, GAO concept of leadership is political leader to demonstrate his skill to developing and directing reform, driving continuous improvement and characterizing the agency's mission in order to drive organization reform [20]. Leadership is known as a skill to influencing and directing people to achieve organization goals. Leadership hold important role because the great leader with a good leadership have commitment, trust and passion to his organization and it became an example for all employee.

Organizational structure describes the organization size, authority, duties and responsibility to achieve organizational goals. Yazdani explain that organization structure recognize the formulation, centralization and integration among employee and division unit in organization [21].

Human Resource (HR) is the great organizational asset which is characteristics on their knowledge, skill and attitude (KSAs). They can manage, develop and give their contribution for their organization. Human resource KSAs are a collective knowledge among all employee in organization and it explain how employee coordinate, share, distribute and combine knowledge [22]. Knowledge is a cognitive ability of remembering, relating and judging idea. Knowledge according to Firestone is beliefs (in minds), expe- riences, ability to understand and adapt, sometimes it's difficult to share [23]. Skills are psycho motor abilities of specific tasks that someone had. Attitudes are affective abilities that represent a state of mind, feeling or beliefs. Sometimes attitudes is related to someone behavior.

Human Resource/Human Capital Process. Ishak et all explain that human resource/human capital process is several human resource practices consider to enhance organization performance [24]. According to PPM Management HR/HC processes are acquisition, development, engagement and retention. $\mathrm{HR} / \mathrm{HC}$ acquisition consists of planning and control employee starting from recruitment, selection and placement. HR/HC development is defined as people development through career management and competency development. $\mathrm{HR} / \mathrm{HC}$ engagement is how to manage employee satisfaction and relation to the organization. HR/ $\mathrm{HC}$ retention determine as a program to evaluate employee performance to get rewards.

Policy is a principles basic plan for execute a job and how to act. Policy defines the boundaries of each job and act. According to Jones, policy define as action plan to guide decisions and achieve outcomes in each organization area [25].

These factors are suitable for government as hierarchical and bureaucratic organization in human resource managerial perspective. Because this research case study is implemented in the hierarchical and bureaucratic organization. This result factor can drive the different organizational culture to be KM culture and build KM environment in order to achieve organizational goals and competitive advantages through KM. For whole steps in implementing KM can be reached by a strong leadership from the top management level in BKN with a high commitment. The organization leader also has to delegate the authority, duties and responsibilities for implementation this program. In order to implement properly and appropriately, the human capital manager should make a right policy and procedure. The manager should make a planning program, schedule and performance indicator of each step also monitoring and reviewing.

\section{References}

[1] Agndal, Henrik, and Ulf Nilsson. "Generation of Human and Structure Capital: Lesson from Knowledge Management." The Electronic Journal of Knowledge Management Volume 4 Issue 2 (2006): 91-98. Web. 27 Sept. 2013.

[2] Bercerra, I. Fernandez, Avelino Gonzalez and Rajiv Sabherwal. Knowledge Management Challenges, Solution, and Techno- 
logies. Upper Saddle River, New Jersey, NJ: Prentice Hall, 2004.

[3] Turban, Efraim., Jay E. Aronson and TingPeng Liang. Decision Support Systems and Intelligent Systems. $7^{\text {th }}$ Edition. Pearson/ Prentice Hall, 2005.

[4] Boynton, Andrew C and Robert W. Zmud. An Assessment of Critical Success Factor. Sloan Management Review (pre-1986). Summer (1984): 17-27.

[5] Mathi, Kavindra. Key Success Factor of Knowledge Management. Master Thesis. University of Applied Science/FH Kempten, Germany, 2004.

[6] Kaplan, Robert S. and David P. Norton. Rev. of Measuring the Strategic Readiness of Intangible Assets. by Harvard Business. Harvard Business School Press. Boston (2004): 52-60.

[7] Vequist, David G. and Mark S. Teachout. "a Conceptual System Approach for the Relationship between Collaborative Knowledge Management (CKM) and Human Capital Management (HCM)”. IEEE. (2006):150156.

[8] Liebowitz, Jay and John, Hopkins. "Linking Knowledge Management with Human Capital Strategy Development." IACS International Conference. Volume V, Issue in Information System, No.1. (2004):194-200.

[9] Tan, Cheng Lin and Aizzat Mohd Nasurdin. "Human Resource Management Practice and Organizational Innovation: Assessing the Mediating Role of Knowledge Management Effectiveness". Electronic Journal of Knowledge Management Volume 9 Issue 2. (2011): 155-167. Web. 20 Okt. 2013.

[10] Okoli, Chitu and Suzanne D. Pawlowski. "The Delphi Method as Research Tool : an Example, Design Cnsiderations and Applications". Journal of Information and Management. Volume 42, Issue 1 (2004): 15 -29. Web. 21 Okt 2013.

[11] Hsu, Cia-Chien. and Brian A. Standford. "Practical Assessment Research and Evaluation." Practical Assessment, Research \& Evaluation, Vol 12. No. 10 (2007): 1-8. Web. 20 Okt. 2013.

[12] Hora, Stephen C. "Expert Judgment Elicitation Methods." Research Project Summaries. Paper 65.(2008): 1-7. Web. 1 Nov. 2013.

[13] Asoh, Derek, Salvator Belardo and Robert Neilson. "Knowledge Management: Issue, Challenges and Oportunities for Governmnet in the New Economy." Proceedings of the $35^{\text {th }}$ Hawaii International Conference on Sys- tem Sciences. 7 - 10 Jan. 2002. Hawaii. (2002): 2-10.

[14] Cong, Xiaoming and Kaushik V. Pandya. "Issue of Knowledge Management in the Public Sector." The Electronic Journal of Knowledge Management Volume 1 Issue 2 (2003): 25-32. Web. 20 Okt. 2013.

[15] Winkelen, Christine van and Jane McKenzie. "Integrating Individual and Organisational Learning Initiatives: Working Across Knowledge Management and Human Resource Management Functional Boundaries." The Electronic Journal of Knowledge Management Volume 5 Issue 4. (2007): 527-538. Web. 20 Okt. 2013.

[16] Shirazi, Ali, Saeed Mortazavi and Naser Pour Azad. "Factor Affecting Employees' Readiness for Knowledge Management." European Journal of Economics, Finance and Adminstrative Sciences. Issue 33. (2010): 167-177. Web. 25 Sept. 2013.

[17] Biygautane, Mhamed and Khalid Al-Yahya. "Knowledge Management in the UAE's Public Sector: The Case of Dubai." The Gulf Research Meeting Conference. July. 2011. UK (2011): 1-34.

[18] Noor, Noorazah Md, and Juhana Salim. "Factor Influencing Employee Knowledge Sharing Capability in Electronic Government Agencies in Malaysia." International Journal of Computer Science Issue, Vol. 8, Issue 4, No. 2. (2011): 106-114. Web. 11 Okt. 2013.

[19] Mozaffari, Farough Amin. "A study of Relationship between Organizational Culture and Leadership". International Conference on Applied Econimics-ICOAE. (2008): 679688.

[20] GAO. "A Model of Strategic Human Capital Ma-nagement." GAO-02-373SP. Washington, D.C. 15 March. (2002): 1-45

[21] Yazdani, Badr., Yaghoubi, Nour M. and Masoume Hajiabadi. "Critical Success Factor for Knowledge Management in Organization: An Empirical Assessment". Euroupean Journal of Humanities and Social Sciences. Volume 3. No. 1. (2011): 96-117.

[22] Zhao, Zheng Jane., Guthrie, James P. and Hui Liao. "HRM Configurations, KSAs, Motivations and Knowledge Creation: A Multilevel Model." The Electronic Journal of Knowledge Management Volume 5 Issue 4. (2007): 527-538. Web. 20 Okt. 2013.

[23] Firestone, Joseph M. "Key Issue in Knowledge Management". Journal of the Knowledge Management Consortium International. Vol. One. No. Three. 15 Apr. 2001. (2001): 8-38. 
[24] Ishak, Norhaiza. Eze, Uchenna C. and Lew Sook Ling. "Integrating Knowledge Management and Human Resource Management for Sustainable Performance". Journal of Organizational Knowledge Management. Vol.
2010. Article ID. 322246 (2010):1-13. Web. 11 Nop.2013.

[25] Jones, Harry. "Policy-making as discource: a review of recent knowledge-to-policy literature". A Joint IKM-ODI Working Paper No. 5. (2009): 1-37. 